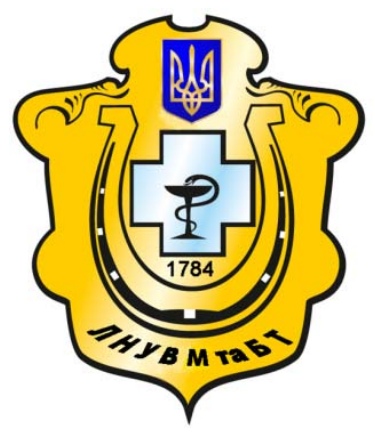

Науковий вісник Львівського національного університету ветеринарної медицини та біотехнологій імені С.3. Гжицького

Scientific Messenger of Lviv National University of Veterinary Medicine and Biotechnologies named after S.Z. Gzhytskyj

doi:10.15421/nvlvet7730

ISSN 2518-7554 print

ISSN 2518-1327 online

$\underline{\text { http://nvlvet.com.ua/ }}$

УДК 594.124:504.423:632.95: 639.2

\title{
Вивчення показників безпечності мідій при їх технологічній обробці щодо вмісту хлорорганічних пестицидів
}

\author{
I.А. Фодченко ${ }^{1}$, В.В. Касянчук², С.В. Ващик ${ }^{1}$, Г.А. Скрипка ${ }^{3}$ \\ irenfodchenko@gmail.com, vkasianchuk@yandex.ru,VEV0902@yandex.ru \\ ${ }^{1}$ Сумський національний аграрний університет, \\ вул. Герасима Кондратьєва, 160, м. Суми, 40000, Україна; \\ ${ }^{2}$ Сумський державний університет, вул. Римського-Корсакова, 2, м. Суми, 40007, Украӥна; \\ ${ }^{3}$ Одеський філіал державного науково-дослідного інституту з лабораторної діагностики \\ та ветеринарно- санітарної експертизи, м. Одеса, Україна
}

В статті розглянуто проблему безпечності мідій щуодо вмісту хлорорганічних пестицидів (ХОП). Встановлено, щңо

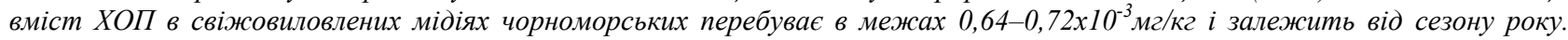
Найбільший вміст ХОП реєстрували в осінній період.

Наведено порівняльний аналіз результатів токсикологічних досліджень мідій (вміст хлорорганічних пестицидів) прибережної зони Одеської області після впливу таких видів технологічної обробки, як проварювання, заморожування $i$ маринування. Дослідженнями на 4-х дослідних групах проб мідій встановлено, щчо при їх проварюванні протягом 10 хв при $100{ }^{\circ} \mathrm{C}$ вміст ХОП в них порівняно з початковим рівнем зменшується від 71,6\% до 63,3\%; процес заморожування при температурі $-18{ }^{\circ} \mathrm{C}$ протягом однієї доби знижує кількість ХОП від 65\% до 63,6\%; технологічна обробка маринуванням від $85 \%$ до $92,3 \%$.

Ключові слова: безпечність чорноморських мідій, токсикологічні показники, хлорорганічні пестичиди, технологічна обробка.

\section{Изучение показателей безопасности мидий при их технологической обработке относительно содержания хлорорганических пестицидов}

\author{
И.А. Фодченко ${ }^{1}$, В.В. Касянчук ${ }^{2}$, Е.В. Ващик ${ }^{1}$, Г.А. Скрипка ${ }^{3}$ \\ irenfodchenko@gmail.com, vkasianchuk@yandex.ru,VEV0902@yandex.ru \\ ${ }^{1}$ Сумский национальный аграрный университет, \\ ул. Герасима Кондратьева, 160, г. Сумьл, 40000, Украина; \\ ${ }^{2}$ Сумский государственный университет, ул. Римского-Корсакова, 2, Сумы, 40007, Украина, \\ ${ }^{3}$ Одеський филиал государственного научно-исследовательского института по лабораторной диагностике и \\ ветеринарно-санитарной экспертизы, г. Одесса, Украина \\ В статье рассмотрена проблема безопасности мидий по содержанию хлорорганических пестицидов (ХОП). \\ Установлено, что содержание ХОП в свежевыловленных мидиях черноморских находится в пределах 0,64-0,72x10-3 мг/кг $u$ \\ зависит от сезона года. Наибольшее содержание ХОП регистрировали в осенний период. \\ Приведен сравнительный анализ результатов токсикологических исследований мидий (содержание хлорорганических \\ пестииидов) прибрежной зоны Одесской области после воздействия такой технологической обработки как проваривание, \\ замораживание и маринование. Исследованиями на 4-х исследовательских группах проб мидий установлено, что при их \\ проваривании в течение 10 мин при $100{ }^{\circ} \mathrm{C}$ содержание ХОП в них по сравнению с начальным уровнем уменьшается от
}

\section{Citation:}

Fodchenko, I.A., Kasyanchuk, V.V., Vaschyk, E.V., Skrypka, G.A. (2017). Study safety indicators of copper processing of technological content organochlorine pesticides. Scientific Messenger LNUVMBT named after S.Z. Gzhytskyj, 19(77), 137-142. 
71,6\% до 63,3\%; прочесс замораживания при температуре $-18{ }^{\circ} \mathrm{C}$ в течение суток снижает количество ХОП от $65 \%$ до 63,6\%; технологическая обработка маринованием - от $85 \%$ до 92,3\%.

Ключевые слова: безопасность черноморских мидий, токсикологические показатели, хлорорганические пестициды, технологическая обработка.

\title{
Study safety indicators of copper processing of technological content organochlorine pesticides
}

\author{
I.A. Fodchenko ${ }^{1}$, V.V. Kasyanchuk ${ }^{2}$, E.V. Vaschyk ${ }^{1}$, G.A. Skrypka ${ }^{3}$ \\ irenfodchenko@gmail.com, vkasianchuk@yandex.ru, VEV0902@yandex.ru
}

${ }^{1}$ Sumy National Agrarian University, Gerasim Kondratyev Str., 160, Sumy, 40000, Ukraine;

${ }^{2}$ Sumy State University, Rimsky-Korsakov 2, Sumy, 40007, Ukraine;

${ }^{3}$ Odessa branch of the State Research Institute of Laboratory Diagnostics and Veterinary Expertise, Odessa, Ukraine

In the article the problem of safety mussels content of organochlorine pesticides. We investigated these toxicants: dyhlordyfeniltryhlormetylmetan (DDT) and $\gamma$-hexachlorocyclohexane ( $\gamma$-HCH - lindane) are classified as "possible» carcinogen to humans and listed on the Stockholm Convention as a persistent organic pollutants. Established that the content of DDT and $\gamma$-HCH in freshly Black Sea mussels within $0.72 \times 10^{-3} \mathrm{mh} / \mathrm{kg},-0.64 \times 10^{-3} \mathrm{mh} / \mathrm{kg}$, depending on the season. The highest content of organochlorine pesticides registered in the autumn.

Established in seawater, after holding mussels one day, three days and six days (with the addition of DDT 20x10 $0^{-3} \mathrm{mh} / \mathrm{kg}$ ) remained under $3 \%, 13 \%, 12 \%$ of the initial concentration introduced. In the water, after adding $200 \times 10^{-3} \mathrm{mg} / \mathrm{kg}_{\text {of }} \mathrm{DDT}$ after holding mussels at the above exposure remaining $6 \%$ of the initial concentration of the pesticide introduced. This fact indicates the cumulative properties of copper relative to DDT. In sea water, with the addition of $\gamma-H C H 20 \times 10^{-3} \mathrm{mg} / \mathrm{l}$ after holding mussels one day, three days and six days left respectively 20\%, 15\%, 16\% of the initial concentration introduced. And with the addition $200 \times 10^{-3} \mathrm{mg} / \mathrm{L} \gamma-\mathrm{HCH}$, after holding mussels at the above exposure remains 13\%, 20\%, 20\% of the initial concentration of the pesticide introduced. It also indicates that the mussels accumulate organochlorine pesticides from water.

The comparative analysis of results of toxicological studies of mussels (the content of organochlorine pesticides) coastal zone of Odessa region after exposure to these types of technological processing as are boiled, freezing and pickling. Research on 4 experimental groups mussel samples found average content of DDT in meat mussel concentrations $18.48 \times 10^{-3} \mathrm{mg} / \mathrm{kg}$ and $172.22 \times 10^{-3} \mathrm{mg} / \mathrm{kg}$ (I, II group) after are boiled decreased by $64.6 \%$ and $63.3 \%$; marinating process reduced the concentration of DDT in $86.3 \%$ and $82 \%$; by freezing the level of DDT decreased by $65.3 \%$ and $63,6 \%$ and the average content in meat $\gamma \mathrm{HCH}$ concentrations in mussels $17.83 \times 10^{-3} \mathrm{mg} / \mathrm{kg}$ and $165.90 \times 10^{-3} \mathrm{mg} / \mathrm{kg}$ (III and IV group) after are boiled decreased by $64.6 \%$ and 71.6\%; marinating process reduced the concentration of $\gamma \mathrm{HCH}$ at $92.3 \%$ and $85 \%$; by freezing level $\gamma \mathrm{HCH}$ decreased by $65 \%$ and $65.3 \%$. It is noted that more sensitive to technological treatment was $\gamma$-HCH and more sustainable - DDT and marinating were most effective in reducing the content of organochlorine pesticides.

Key words: Black Sea mussels safety, toxicological indicators, organochlorine pesticides, processing technology

\section{Вступ}

Морепродукти $є$ одним із забруднювачів навколишнього середовища. Крізь молюска проходять тонни води, накопичуючи токсичні речовини, що може бути небезпечним не тільки для мідій, а й для людини як споживача (Zhiljakova, 2004). Однією 3 найважливіших проблем суспільства $є$ мінімізація негативного впливу ХОП на людину, дія яких супроводжується зниженням резистентності організму, виснаженням, збільшенням частки захворювань щитоподібної залози, атеросклерозу, онкології, діабету та ін.

ХОП, які належать до найбільш значущих стійких органічних забруднювачів, особливо такі пестициди, як ГХЦГ, ДДТ та інші, відповідно до Міжнародних конвенцій про захист морського середовища, класифікують як найбільш небезпечні забруднювачі довкілля. Ці речовини володіють токсичними властивостями навіть в малих концентраціях. Вони здатні накопичуватися в тканинах морських організмів і при тривалому впливі навіть у малих дозах спричиняти токсичну дію, що проявляється у порушенні репродуктивної, нервової, ендокринної, імунної систем, а також проявляють тератогенний ефект (Malinin et al., 2002).

Велику небезпеку становить забруднення води ГХЦГ і його ізомерами, оскільки вони практично не розчиняються в ній i можуть накопичуватися у великих кількостях. Існують і експериментальні дані про наявність канцерогенних та мутагенних властивостей ГХЦГ (Pozdnjakovskij, 2007).

За даними літературних джерел ДДТ, алдрин, гептахлор, викликали рак у піддослідних тварин, особливо рак печінки у мишей. В організмі людей, що померли від раку, цирозу печінки, високого кров'яного тиску, крововиливів у мозок i розм'якшення мозку, містились досить високі рівні ДДТ та метаболіти ДДД і ДДЕ.

Небезпека ХОП полягає в поширенні у навколишньому середовищі, накопиченню в морях, океанах, що супроводжується їх міграцією по харчовому ланцюгу, з осіданням в організмі морських мешканців, особливо зважаючи на те, що період напіврозпаду цих сполук сягає 15-20 років (Yakubchak et al., 2011).

Пестициди можуть накопичуватися в продовольчій сировині i харчових продуктах внаслідок безконтрольного використання та 
незважаючи на те, що більшість стійких органічних забруднювачів (ДДТ, гептахлор, ГХЦГ) були заборонені та видалені з ринку, їх досі знаходять у вимірних кількостях в навколишньому середовищі та продуктах харчування. Аналіз літературних джерел показав, що пестициди, потрапляючи в організм людини і накопичуючись там у великих кількостях, призводять до розвитку багатьох хронічних захворювань і гострих отруєнь, а також до збільшення кількості вроджених аномалій розвитку і дитячої смертності. Пестициди надовго затримуються в організмі, деякі залишаються в ньому назавжди. Викликають порушення серцевої, ендокринної, нервової та імунної систем, що було доведено при дослідженнях на тваринах (Ukrainska ahrarna konferentsiia, 2010).

Технологічна обробка - один із можливих засобів знизити вміст ХОП (Barbosa, 2017). За даним деяких авторів, при кулінарній обробці їжі ДДТ майже не руйнується.

Отже, питання вивчення впливу ХОП на мідій та негативні побічні наслідки при вживанні їх у їжу $є$ актуальним на даний час.

Мета дослідження. Оцінити вплив різних видів технологічної обробки на вміст забруднюючих

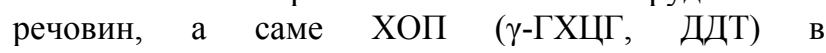
чорноморських мідіях. Відповідно до цієї мети були поставлені такі завдання:

1. Визначити вміст ХОП у воді до та після витримки чорноморських мідій в акваріумах з різною концентрацією пестициду (ДДТ, $\gamma$-ГХЦГ).
2. Визначити вміст ХОП в чорноморських мідіях до та після витримки живих чорноморських мідій в акваріумах з різною концентрацією пестициду (ДДТ, $\gamma$-ГХЦГ). Провести порівняльний аналіз значень концентрацій ХОП з їх фактичним вмістом у воді та мідіях.

3. Дослідити та вивчити вплив різних технологій обробки (проварювання, заморожування та маринування) на вміст хлорорганічних пестицидів у чорноморських мідіях та довести безпеку для подальшого вживання такого продукту в їжу.

\section{Матеріал і методи досліджень}

Дослідження проводились на базі Одеського філіалу державного науково-дослідного інституту 3 лабораторної діагностики та ветеринарно-санітарної експертизи. Матеріалом для досліджень були живі мідії та морська вода.

Було проведено два етапи дослідів:

- 1-й етап полягав у вивченні рівня накопичення живими мідіями ХОП з морської води (ДДТ, $\gamma$ ГХЦГ);

- 2-й етап включав експериментальне вивчення впливу технологічної обробки мідій на динаміку концентрації ХОП (ДДТ, $\gamma$-ГХЦГ) в них.

Для реалізації завдань 1-го етапу дослідів були сформовані чотири дослідні групи мідій, яких витримували у морській воді 3 додаванням різних концентрацій ДДТ та $\gamma$ ГХЦГ. Схеме проведення досліду наведено у табл. 1.

Таблиия 1

Схема проведення досліду на живих чорноморських мідіях

\begin{tabular}{|c|c|c|c|c|}
\hline \multirow{2}{*}{ Групи } & \multicolumn{3}{|c|}{ Експозиція, діб } \\
\cline { 2 - 5 } & \multicolumn{2}{|c|}{$1,3,6$} & \multicolumn{2}{c|}{$1,3,6$} \\
\cline { 2 - 5 } & \multicolumn{2}{|c|}{ ДДТ, мг/л ГХЦГ, мг/л } \\
\hline Перша дослідна & 0,02 & 0,2 & - & - \\
\hline Друга дослідна & 0,02 & 0,2 & 0,02 & 0,2 \\
\hline Третя дослідна & - & - & 0,02 & 0,2 \\
\hline Четверта дослідна & - & - & - & - \\
\hline Контрольна & - & - & & - \\
\hline
\end{tabular}

Кожну з дослідних груп мідій досліджували на вміст ХОП після витримки в акваріумах згідно 3 умовами досліду. Досліди щодо визначення вмісту ХОП в м'язах мідій після проварювання, маринування та заморожування проводили на дослідних групах мідій згідно з експозицією, яка вказана у таблиці 1.

Визначення вмісту ХОП в мідіях проводили методом газової хроматографії.

Другий етап досліджень був реалізований шляхом використання таких методів технологічної обробки мідій, як проварювання, маринування, заморожування. Проварювання живих мідій проводили в мушлях на середньому вогні протягом 10 хвилин від закипання, поки більшість 3 них не відкриється; процес маринування здійснювали шляхом витримування мідій у маринаді (вода, сіль, цукор, оцет (9\%), олія, спеції) в холодильнику $\left(\mathrm{t}-4^{\circ} \mathrm{C}\right)$ одну добу; заморожування проводили в морозильній камері при температурі $-18{ }^{\circ} \mathrm{C}$ протягом доби.

\section{Результати та їх обговорення}

На першому етапі досліджень були отримані результати вмісту ХОП у морській воді та чорноморських мідіях до та після витримки мідій в акваріумах з різною концентрацією пестициду, що відображено в таблицях 2-3.

В морській воді, після витримки мідій одну добу,

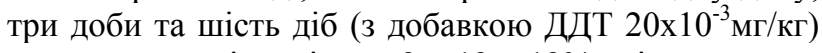
залишилось відповідно 3, 13, 12\% від внесеної початкової концентрації. У воді, в яку додали $200 \times 10^{-3}$ мг/кг ДДТ, після витримки мідій за вищевказаною експозицією, залишилося по 6\% від внесеної початкової концентрації пестициду. Цей факт вказує на кумулятивні властивості мідій відносно ДДТ.

Хроматографічний аналіз показав зменшення внесеної добавки $\gamma$-ГХЦГ в морській воді та збільшення цього пестициду в тканинах мідій (табл. 3). 
Вміст ХОП у морській воді після витримки мідій за умови додавання ДДТ*

\begin{tabular}{|c|c|c|c|}
\hline \multirow[t]{2}{*}{$\begin{array}{c}\text { Найменування } \\
\text { ХОП }\end{array}$} & \multirow{2}{*}{$\begin{array}{c}\text { Вміст ХОП в морській воді до } \\
\text { внесення добавки } \\
\text { ДДТ мг/л, } 10^{-3} \\
\end{array}$} & \multicolumn{2}{|c|}{$\begin{array}{c}\text { Залишок пестицидів у воді у мг/л, } 10^{-3} \text {, після витримки мідій } \\
\text { в акваріумі з додаванням ДДТ } 3 \text { концентраціями: }\end{array}$} \\
\hline & & $20 \times 10^{-3}$ мГ/л & $200 \times 10^{-3}$ мг/л \\
\hline \multicolumn{4}{|c|}{1 доба } \\
\hline ДДТ & $0,74 \pm 0,2$ & $0,34 \pm 0,1$ & $8 \pm 0,2$ \\
\hline \multicolumn{4}{|c|}{3 доби } \\
\hline ДДТ & $0,74 \pm 0,1$ & $2,7 \pm 0,1$ & $25 \pm 0,2$ \\
\hline \multicolumn{4}{|c|}{6 діб } \\
\hline ДДТ & $0,74 \pm 0,3$ & $2,4 \pm 0,3$ & $22 \pm 0,3$ \\
\hline
\end{tabular}

Примітка $*-\mathrm{P} \leq 0,05$

Таблиия 3

Вміст ХОП у морській воді після витримки мідій за умови додавання гамма ГХЦГ*

\begin{tabular}{|c|c|c|c|}
\hline \multirow[t]{2}{*}{ Найменування ХОП } & \multirow{2}{*}{$\begin{array}{c}\text { Вміст ХОП в морській воді до вне- } \\
\text { сення добавки } \\
\gamma \text {-ГХЦГ мг/л, } 10^{-3}\end{array}$} & \multicolumn{2}{|c|}{$\begin{array}{l}\text { Залишок пестицидів у воді у мг/л, } 10^{-3} \text {, після витримки } \\
\text { мідій в акваріумі } 3 \text { добавкою } \gamma \text { ГХЦГ з концентраціями: }\end{array}$} \\
\hline & & $20 \times 10^{-3} \mathrm{мг} / л$ & $200 \times 10^{-3}$ мГ/л \\
\hline \multicolumn{4}{|c|}{1 доба } \\
\hline$\gamma$-ГХЦГ & $1,0 \pm 0,1$ & $4,18 \pm 0,2$ & $26,9 \pm 0,1$ \\
\hline \multicolumn{4}{|c|}{3 доби } \\
\hline 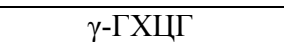 & $1,0 \pm 0,2$ & $3,1 \pm 0,3$ & $13,47 \pm 0,1$ \\
\hline \multicolumn{4}{|c|}{6 діб } \\
\hline 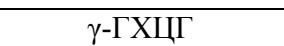 & $1,0 \pm 0,1$ & $3,28 \pm 0,2$ & $39,6 \pm 0,3$ \\
\hline
\end{tabular}

Примітка *-P $\leq 0,05$

В морській воді, після витримки мідій одну добу, три доби та шість діб з добавкою $\gamma$-ГХЦГ 20х10-3 мг/л залишилось відповідно 20, 15, 16\% від внесеної початкової концентрації. А $з$ добавкою $200 \times 10^{-3}$ мг/л $\gamma$-ГХЦГ, після витримки мідій за вищевказаною експозицією, залишилося 13\%, 20\%, 20\% від внесеної початкової концентрації пестициду. Це також вказує на те, що мідії накопичують ХОП з води.

На другому етапі досліджень були отримані результати впливу різних технологій обробки на вміст ХОП в мідіях чорноморських за різної експозиції та концентрації ДДТ. Результати досліджень, відображені в таблиці 4, свідчать, що після проварювання мідій вміст ХОП зменшився від 59\% до 69\%; при маринуванні - від 87 до 88\%; після заморозки - від 59 до 69\%.

Після витримки в акваріумі мідій при концентрації ДДТ $200 \times 10^{-3}$ мг/кг та після різних видів обробки отримали результат: при проварюванні вміст ХОП зменшився до 67\%, після маринування - до $89 \%$ та після заморожування - до $67 \%$ (табл. 5).
Результат впливу різних технологій обробки на вміст ХОП в мідіях чорноморських за різної експозиції та концентрації $\gamma$-ГХЦГ відображено в таблицях 6-7. Під дією різних видів технологічних обробок вміст ХОП зменшився в мідіях, тобто обробка руйнує частину пестицидів. Результати аналізу показали зменшення залишкової кількості ХОП при проварюванні на 66\%, при маринуванні - на 99\% та при заморожуванні - на $72 \%$.

Як видно з таблиці, найкращий ефект зменшення вмісту ХОП в мідіях виявлено при маринуванні, практично на однакових рівнях після проварювання та після заморожування. При додаванні в акваріум 3 морською водою 200×10 $10^{-3}$ мг/кг $\gamma$ ГХЦГ виявлено зменшення вмісту ХОП в мідіях після проварювання до $75 \%$, при маринуванні - до $94 \%$ та після заморожування до 70\%. Дані, що наведені в таблицях 4-7, свідчать про те, що технологічна обробка зменшує вміст ХОП в мідіях. Найбільший ефект зниження вмісту цих пестицидів в мідіях було відмічено при маринуванні.

Табличяя 4

Вплив різних технологій обробки на вміст ХОП в мідіях чорноморських за умови додавання ДДТ в концентрації $20 \times 10^{-3} \mathrm{Mг} / \Omega^{*}$

\begin{tabular}{|c|c|c|c|c|c|}
\hline \multirow{2}{*}{$\begin{array}{l}\text { Найменування } \\
\text { ХОП }\end{array}$} & \multicolumn{2}{|c|}{$\begin{array}{l}\text { Вміст ХОП в мідіях, } \\
\text { мг/кг, } 10^{-3}\end{array}$} & \multicolumn{3}{|c|}{$\begin{array}{c}\text { Вміст ХОП після технологічної обробки мг/кг, } \\
10^{-3}\end{array}$} \\
\hline & Без добавки & $\begin{array}{c}3 \text { добавкою } \\
20 \times 10^{-3} \text { мг/л ДДТ }\end{array}$ & варені & маринування & після заморозки \\
\hline \multicolumn{6}{|c|}{1 доба } \\
\hline ДДТ & $0,72 \pm 0,2$ & $19,0 \pm 0,1$ & $7,96 \pm 0,2$ & $2,56 \pm 0,2$ & $7,97 \pm 0,1$ \\
\hline \% зменшення ДДТ & & & 59 & 87 & 59 \\
\hline \multicolumn{6}{|c|}{3 доби } \\
\hline ДДТ & $0,72 \pm 0,1$ & $17,74 \pm 0,2$ & $6,23 \pm 0,2$ & $2,99 \pm 0,1$ & $5,85 \pm 0,3$ \\
\hline \% зменшення ДДТ & & & 66 & 84 & 68 \\
\hline \multicolumn{6}{|c|}{6 діб } \\
\hline ДДТ & $0,72 \pm 0,2$ & $18,70 \pm 0,3$ & $5,74 \pm 0,1$ & $2,17 \pm 0,1$ & $5,7 \pm 0,2$ \\
\hline \% зменшення ДДТ & & & 69 & 88 & 69 \\
\hline Середнє & & 18,48 & 64,6 & 86,3 & 65,3 \\
\hline
\end{tabular}

Примітка *-P $\leq 0,05$ 
Вплив різних технологій обробки на вміст ХОП в мідіях чорноморських за умови додавання ДДТ в концентрації $200 \times 10^{-3} \mathrm{мг/л*}$

\begin{tabular}{|c|c|c|c|c|c|}
\hline \multirow{2}{*}{$\begin{array}{l}\text { Найменування } \\
\text { ХОП }\end{array}$} & \multicolumn{2}{|c|}{$\begin{array}{l}\text { Вміст ХОП в мідіях } \\
\text { мг/кг, } 10^{-3} \\
\end{array}$} & \multicolumn{3}{|c|}{$\begin{array}{l}\text { Вміст ХОП після технологічної обробки мг/кг, } \\
110^{-3}\end{array}$} \\
\hline & Без добавки & $\begin{array}{c}3 \text { добавкою } \\
200 \times 10^{-3} \text { мг/л ДДТ }\end{array}$ & варені & маринування & після заморозки \\
\hline \multicolumn{6}{|c|}{1 доба } \\
\hline ДДТ & $0,72 \pm 0,2$ & $173,44 \pm 0,2$ & $59,81 \pm 0,1$ & $24,82 \pm 0,2$ & $59,0 \pm 0,3$ \\
\hline \% зменшення ДДТ & & & 67 & 86 & 67 \\
\hline \multicolumn{6}{|c|}{3 доби } \\
\hline ДДТ & $0,72 \pm 0,1$ & $170,14 \pm 0,2$ & $62,21 \pm 0,2$ & $18,37 \pm 0,1$ & $65,41 \pm 0,1$ \\
\hline \% зменшення ДДТ & & & 64 & 89 & 62 \\
\hline \multicolumn{6}{|c|}{6 діб } \\
\hline ДДТ & $0,72 \pm 0,2$ & $173,10 \pm 0,3$ & $73,4 \pm 0,2$ & $52,4 \pm 0,2$ & $68,01 \pm 0,2$ \\
\hline \% зменшення ДДТ & & & 59 & 71 & 62 \\
\hline Середнє & & 172,22 & 63,3 & 82,0 & 63,6 \\
\hline
\end{tabular}

Примітка *-P $\leq 0,05$

Табличя 6

Результат впливу різних технологій обробки на вміст ХОП в мідіях чорноморських за умови додавання $\gamma$-ГХЦГ в концентрації 20x10 ${ }^{-3}$ мг/л*

\begin{tabular}{|c|c|c|c|c|c|}
\hline \multirow[b]{2}{*}{ Найменування ХОП } & \multicolumn{2}{|c|}{ Вміст ХОП в мідіях мг/кг, $10^{-3}$} & \multicolumn{3}{|c|}{$\begin{array}{l}\text { Вміст ХОП після технологічної обробки мг/кг, } \\
10^{-3}\end{array}$} \\
\hline & Без добавки & $\begin{array}{c}3 \text { додаванням } \\
20 \times 10^{-3} \text { мг/л } \\
\gamma \text { ГХЦГ }\end{array}$ & варені & маринування & після заморозки \\
\hline \multicolumn{6}{|c|}{1 доба } \\
\hline$\gamma$ ГХЦГ & $0,64 \pm 0,1$ & $17,20 \pm 0,3$ & $5,54 \pm 0,2$ & $0,09 \pm 0,1$ & $4,86 \pm 0,1$ \\
\hline \% зменшення $\gamma$ ГХЦГ & & & 66 & 99 & 72 \\
\hline \multicolumn{6}{|c|}{3 доби } \\
\hline$\gamma$ ГХЦГ & $0,64 \pm 0,3$ & $18,24 \pm 0,2$ & $6,69 \pm 0,1$ & $2,66 \pm 0,1$ & $5,91 \pm 0,2$ \\
\hline \% зменшення $\gamma$ ГХЦГ & & & 64 & 86 & 68 \\
\hline \multicolumn{6}{|c|}{6 діб } \\
\hline$\gamma$ ГХЦГ & $0,64 \pm 0,2$ & $18,06 \pm 0,1$ & $6,74 \pm 0,2$ & $1,54 \pm 0,2$ & $8,34 \pm 0,1$ \\
\hline \% зменшення $\gamma$ ГХЦГ & & & 64 & 92 & 55 \\
\hline Середнє & & 17,83 & 64,6 & 92,3 & 65,0 \\
\hline
\end{tabular}

Примітка *-P $\leq 0,05$

Таблиия 7

Результат впливу різних технологій обробки на вміст ХОП в мідіях чорноморських за умови додавання $\gamma$-ГХЦГ в концентрації $200 \times 10^{-3} \mathrm{мг/ \Omega ^{* }}$

\begin{tabular}{|c|c|c|c|c|c|}
\hline \multirow[b]{2}{*}{ Найменування ХОП } & \multicolumn{2}{|c|}{ Вміст в мідіях ХОП мг/кг, $10^{-3}$} & \multicolumn{3}{|c|}{$\begin{array}{l}\text { Вміст ХОП після технологічної обробки мг/кг, } \\
10^{-3}\end{array}$} \\
\hline & Без добавки & 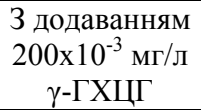 & варені & маринування & після заморозки \\
\hline \multicolumn{6}{|c|}{1 доба } \\
\hline$\gamma$ ГХЦГ & $0,64 \pm 0,2$ & $174,44 \pm 0,2$ & $53,0 \pm 0,2$ & $9,72 \pm 0,1$ & $53,7 \pm 0,1$ \\
\hline \% зменшення $\gamma$ ГХЦГ & & & 70 & 94 & 69 \\
\hline \multicolumn{6}{|c|}{3 доби } \\
\hline$\gamma$ ГХЦГ & $0,64 \pm 0,1$ & $161,53 \pm 0,3$ & $41,0 \pm 0,1$ & $39,3 \pm 0,2$ & $70,3 \pm 0,2$ \\
\hline \% зменшення $\gamma$ ГХЦГ & & & 75 & 76 & 57 \\
\hline \multicolumn{6}{|c|}{6 діб } \\
\hline$\gamma$ ГХЦГ & $0,64 \pm 0,2$ & $161,74 \pm 0,2$ & $48,4 \pm 0,2$ & $24,0 \pm 0,1$ & $47,94 \pm 0,2$ \\
\hline \% зменшення $\gamma$ ГХЦГ & & & 70 & 85 & 70 \\
\hline Середнє & & 165,9 & 71,6 & 85,0 & 65,3 \\
\hline
\end{tabular}

Примітка $*$ - $\mathrm{P} \leq 0,05$

\section{Висновки}

1. Середній вміст ДДТ у м'ясі мідій в концентраціях $18,48 \times 10^{-3}$ мг/кг та $172,22 \times 10^{-3} \mathrm{Mг} / \kappa г$ після проварювання зменшився відповідно на 64,6\% та 63,3\%; процес маринування зменшив концентрацію ДДТ на 86,3\% та 82\%; при заморожуванні рівень ДДТ зменшився на $65,3 \%$ та $63,6 \%$.
2. Середній вміст $\gamma$ ГХЦГ у м'ясі мідій в концентраціях $17,83 \times 10^{-3}$ мг/кг та $165,90 \times 10^{-3}$ мг/кГ після проварювання зменшився відповідно на 64,6\% та $71,6 \%$; процес маринування зменшив концентрацію $\gamma$ ГХЦГ на 92,3\% та 85\%; при заморожуванні рівень $\gamma$ ГХЦГ зменшився на 65\% та 65,3\%.

Відмічено, що більш чутливим до дії технологічної обробки був $\gamma$-ГХЦГ, а більш стійким - 
ДДТ, причому маринування було найефективнішим щодо зниження вмісту ХОП.

Перспективою подальших досліджень буде вивчення ферментного та морфологічного складу мідій за впливу різних концентрацій ХОП.

\section{Бібліографічні посилання}

Zhiljakova, I.G. (2004). Promyshlennoe razvedenie midij i ustric. M.: OOO Izdatel'stvo ACT. Doneck: Stalker (Priusadebnoe hozjajstvo), 102-105 (in Russian).

Malinin, O.A., Hmel'nickij, G.A., Kucan, A.T. (2002). Veterinarnaja toksikologija: Ucheb. posobie dlja stud. vuzov vet. Mediciny. Korsun'-Shevchenk.: ChP Majdachenko, 210-224 (in Russian).

Pozdnjakovskij, V.M. (2007). Jekspertiza ryby, ryboproduktov i obektov vodnogo promysla.
Kachestvo i bezopasnost'. Novosibirsk.: Sibirskoe universitetskoe izdatel'stvo (in Russian).

Yakubchak, O.M., Tiutiun, A.I., Taran, T.V. (2011). Veterynarno-sanitarna ekspertyza ryby ta inshykh hidrobiontiv. Metodychni vkazivky. K.: TsP «KOMPRYNT» (in Ukrainian).

Ukrainska ahrarna konferentsiia (2010). Novyny UAK. Rybne meniu ukraintsiv skhudlo na 15\%. [Elektronnyi resurs]. Rezhym dostupu: http://agroconf.org/ content/ribne-menyu-ukrayinciv-shudlo-na-15 (in Ukrainian).

Barbosa, V. (2017). Effect of cooking on levels of contaminants of emerging concern in commercial seafood. Seafood Safety New Findings \& Innovation Challenges-Abstract Book.

Стаття надійшла до редакиії 23.03.2017 